\title{
VÝZDOBA PÍSNÍ CHVAL BOŽSKÝCH Z KNIHOVNY NÁRODNÍHO MUZEA
}

\author{
Ema Součková (Praha)
}

\begin{abstract}
The Decoration of Písně Chval Božských [Songs of Divine Worship] from the National Museum Library
The handwritten monumental hymn-book discussed was most likely made in the 1560s in the workshop of Jan Táborský of Klokotská Hora, and the decoration was painted by Matěj Hutský of Křivoklát, who was a very sought-after artist in his time. The decoration of the codex follows the usual period template for illuminated songbooks, which were very numerous in the lands of the Bohemian Crown in the 16th century. The figural themes are placed in the margins and are complemented by acanthus leaves with golden droplets, which terminate in pruned branches. On three folios, the painted motifs are furthermore composed on the basis of typological parallelism: a scene from the New Testament is linked to an Old Testament scene, which is also usual in other codices. The manuscript's decoration is, however, not the pinnacle of 16th-century book illumination. The style is loose, sometimes excessively drawn. It is possible that the commissioner, most likely of the burgher elite, preferred the simpler form of illumination because of financial constraints.
\end{abstract}

Keywords: manuscript - hymn-book - 16th century - illumination - Matěj Hutský of Křivoklát

\section{Úvod}

Rukopis, který je z liturgického hlediska kancionálem, ${ }^{1}$ vznikl patrně v 60. letech 16 . století. Sepsán byl zřejmě v písařské dílně Jana Táborského z Klokotské Hory a o jeho výzdobu se s největší pravděpodobností postaral iluminátor Matěj Hutský z Křivoklátu. ${ }^{2}$

Tento rukopis (sign. I A 16), jenž bývá podle vytlačeného nápisu na přední desce vazby nazýván Druhým dílem Písní chval božských, očividně nesouvisí s jiným monumentálním zpěvníkem, který je taktéž chovaný v Knihovně Národního muzea pod signaturou I A $15,{ }^{3}$ což zmiňuje již Pavel Brodský. ${ }^{4}$ Jarmila Vacková ve svých studiích řadí oba kodexy do třetí vrstvy malovaných chorálních knih let 1575-1595, jež podle ní náležejí „,beze zbytku dílně Jana Kantora Starého ", 5 což je ovšem otázka. Tento, tzv. druhý díl (sign. I A 16) totiž obsahuje na ff. 223v-224v básnické akrostichon, jehož počáteční písmena dohromady sdělují „TABORSKAY GAAN", což tedy zjevně identifikuje jméno Jana Táborského z Klokotské Hory. ${ }^{6}$ Jan Táborský mohl být jednak autorem písně na těchto foliích, nebo je dokonce možné, že celý graduál byl sepsán v jeho dílně. V rukopise se naopak nevyskytuje kolofon, který by určoval, že je zhotoven Janem Kantorem Starým. ${ }^{7}$ Pavel Brodský na základě stylu výzdoby rukopis zařadil do 60 . let 16 . století, ${ }^{8}$ tudíž by

1 Písně chval božských (Praha, Knihovna Národního muzea, sign. I A 16, 60. léta 16. století), bibliografie k rukopisu: BARTOŠ 1926, s. 14; VACKOVÁ 1968, s. 384; VACKOVÁ 1989, s. 97; BRODSKÝ 2000, s. 6; BRODSKÝ 2012, s. 23, obr. 291, 292; SOUČKOVÁ 2019, s. 352-355.

2 BRODSKÝ 2000, s. 6. Iluminátor Matěj/Matyáš Hutský z Křivoklátu (1546-1597/1600?) získal vzdělání v zahraničí, patrně v Tyrolsku a později byl členem staroměstského maliřského cechu. Kromě výzdoby rukopisů se věnoval i monumentálnímu umění a vychoval několik žáků, mezi nimiž byl i jeho synovec Šimon Hutský. Výběrová bibliografie k M. Hutskému: MIKOVEC 1853, s. 52-68; CHYTIL 1906, s. 21, 23, 26, 91-97, 167, 189, 190, 195, 196, 199, 301-305; TOMAN 1947, s. 391; VACKOVÁ 1968, s. 384; ŠRONĚK 1997, s. 56-60; BRODSKÝ 2012, s. 44; SOUČKOVÁ 2019, s. 102-131.

3 Písně chval božských (Praha, Knihovna Národního muzea, sign. I A 15, 2. pol. 16. století), bibliografie k rukopisu: BARTOŠ 1926, s. 14; MERHAUTOVÁ-LIVOROVÁ 1953, s. 85; PEŠINA 1954a, s. 253-254; PEŠINA 1954b, s. 287-288; DROBNÁ 1966, s. 235; VACKOVÁ 1968, s. 384; VACKOVÁ 1989, s. 97; BRODSKÝ 2000, s. 5; ŠÁROVCOVÁ 2010a, s. 4-11; SOUČKOVÁ 2019, s. 381-385. Rukopis je digitalizován, viz Manuscriptorium - Digital Library of Written Cultural Heritage [online]. Národní knihovna České republiky. [Cit. 23. 7. 2019]. Dostupné z: http://manuscriptorium.com

${ }^{4}$ BRODSKÝ 2000, s. 6.

5 VACKOVÁ 1968, s. 384; VACKOVÁ 1989, s. 97. Jan Kantor Starý (1531/1532?-1582) byl písař, v jehož dílně, prokazatelně vzniklo několik monumentálních zpěvníků. Kromě toho, že byl měšt’anem na Novém Městě pražském, není o něm známo mnoho informací. Výběrová bibliografie k němu: CHYTIL 1906, s. 191; VACKOVÁ 1989, s. 95; GRAHAM 2006, s. 93.

${ }^{6}$ Jan Táborský z Klokotské Hory (1499/1500?-1572) byl podobně jako Jan Kantor Starý písařem, také majitelem písařské dílny, kde zaměstnával další spolupracovníky. Dále byl autorem řady textů písní. Výběrová bibliografie k němu: TEIGE 1901; CHYTIL 1906, s. 48, 79, 179, 180; KROPÁČEK 1952, s. 121-123; ČERNUŠÁK - ŠTĚDROŇ - NOVÁČEK 1965, s. 749-750; VACKOVÁ 1968, s. 380; PUDILOVÁ 1973; VACKOVÁ 1989, s. 93, 95; GRAHAM 2006, s. 87-92; PUMPRLA 2010, s. 1106-1107; SOUČKOVÁ 2019.

7 Právě kolofon bývá obvyklou součástí kodexů vyšlých od J. Kantora Starého. Např. na fol. 462r Malostranského graduálu (Praha, NK ČR, sign. XVII. A. 3, 1572) se nachází kolofon určující Jana Kantora Starého. Rukopis je digitalizován viz Manuscriptorium - Digital Library of Written Cultural Heritage [online]. Národní knihovna České republiky. [Cit. 23. 7. 2019]. Dostupné z: http://manuscriptorium.com

${ }^{8}$ BRODSKÝ 2000, s. 6. 


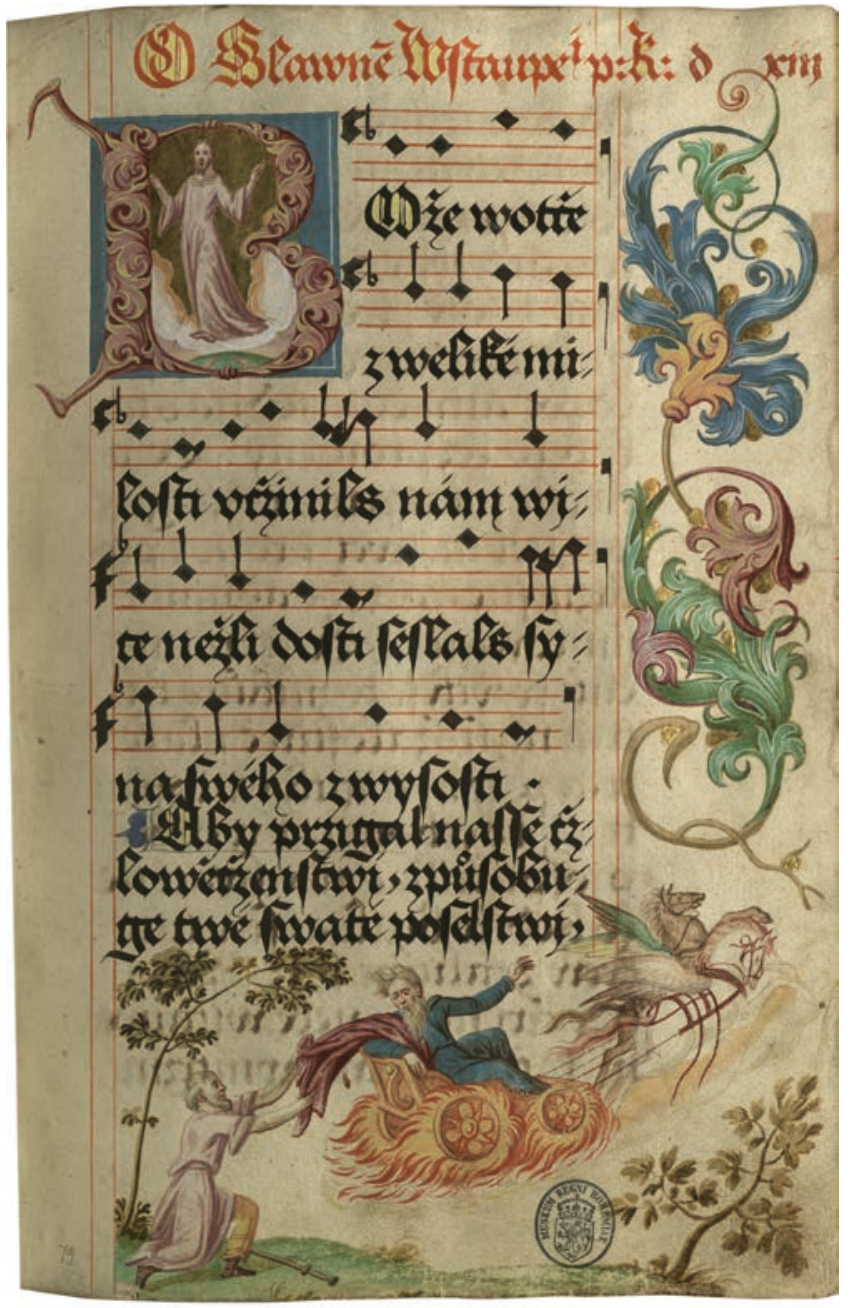

Obr. 1. Písně chval božských. Praha, Knihovna Národního muzea, oddělení rukopisů a starých tisků, sign. I A 16, 60. léta 16. století, fol. 79r. Foto: KNM.

bylo možné, že kodex byl sestaven u J. Táborského, jak je zmíněno výše. ${ }^{9}$

\section{Iluminace Písní chval božských}

První vyzdobenou stranou Písní chval božských (sign. I A 16) je fol. 79r (viz obr. 1), ${ }^{10}$ kde se v iniciále B nachází postava právě na nebe vstupujícího Krista. ${ }^{11}$ Takto zpodobněné

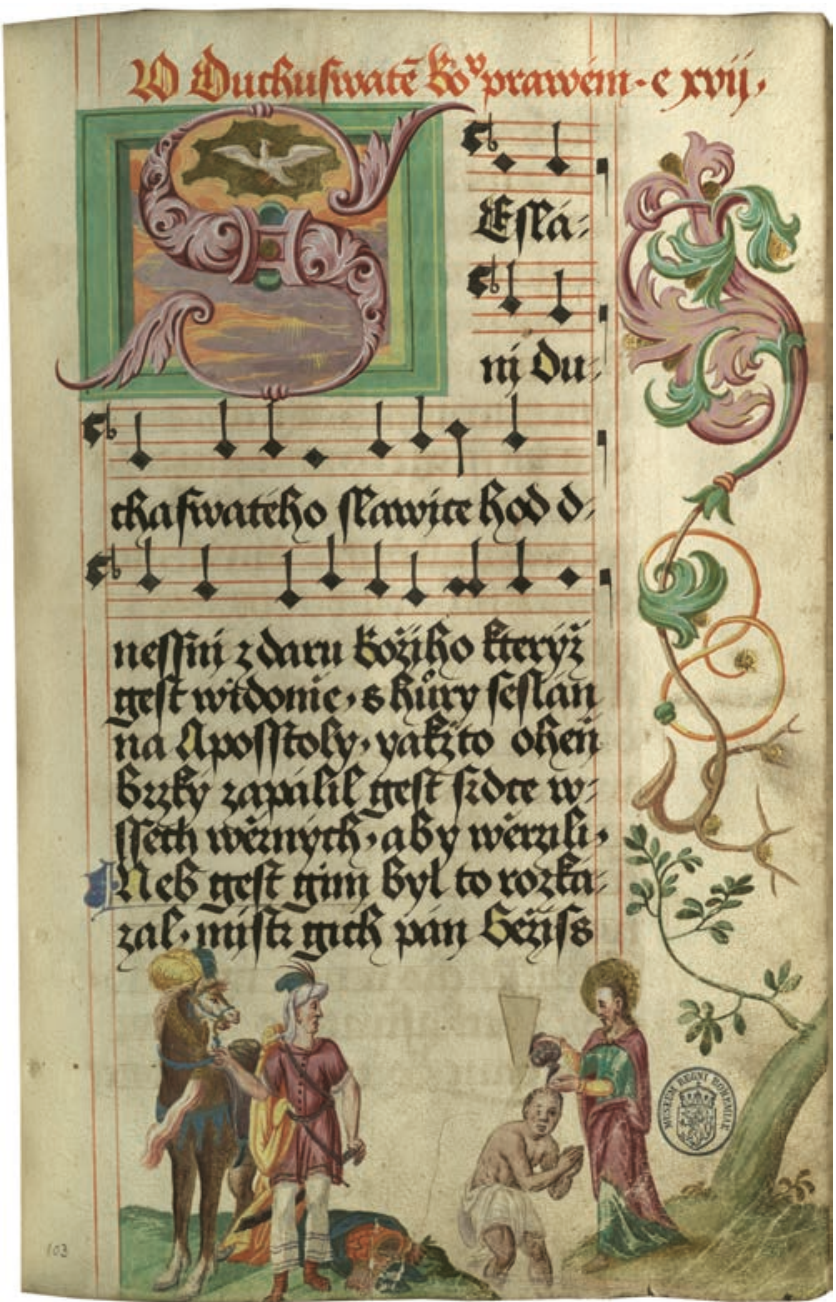

Obr. 2. Písně chval božských. Praha, Knihovna Národního muzea, oddělení rukopisů a starých tisků, sign. I A 16, 60. léta 16. století, fol. 103r. Foto: KNM.

Nanebevstoupení není ve zpěvnících 2. poloviny 16. století obvyklé. Obyčejně lze dohledat výjev s apoštoly, kteří se nacházejí seskupeni kolem nízkého pahorku. Z figury Krista jsou většinou znázorněny jen jeho nohy, vyčuhující zpod oblaku. Tato kompozice se např. objevuje v Graduálu Jakuba Sklenáře na fol. $368 \mathrm{v}^{12}$ nebo v Křižovnickém graduálu na fol. $199 \mathrm{v} .^{13}$

Po pravé straně fol. 79r Písní chval božských se dále nachází akantová rozvilina, doplněná zlatými kapkami

\footnotetext{
9 J. Táborský žil v letech asi 1499/1500 (?) - 1572. Viz bibliografie k němu pozn. 6.

${ }^{10}$ Fol. 79r má rubriku „O Wstaupení Pana Krista“. Litera B uvádí incipit „,Bože wotče z weliké milosti “.

${ }^{11}$ Viz Mk 16,19; L 24,50-53; Sk 1,9-12, více k ikonografii námětu např.: HALL 1975, s. 33-34; ROYT 2006, s. $163-164$.

${ }^{12}$ Graduál Jakuba Sklenáre (Praha, NK ČR, sign. XVII. B. 21, 1572), výběrová bibliografie k rukopisu: TRUHLÁR̆ 1906, s. 28; URBÁNKOVÁ 1957, s. 24; VACKOVÁ 1968, s. 384; VACKOVÁ 1989, s. 97; ŠRONĚK 1997, s. 56; GRAHAM 2006, s. 406-408; ŚÁROVCOVÁ 2011, s. 99\#-100\#, kat. č. 36. Rukopis je digitalizován, viz Manuscriptorium - Digital Library of Written Cultural Heritage [online]. Národní knihovna České republiky. [Cit. 23. 7. 2019]. Dostupné z: http://manuscriptorium.com

${ }^{13}$ Křižovnický graduál - I. díl (Praha, NK ČR, depositum knihovny Rytiřrského řádu Křižovníků s červenou hvězdou, sign. Křiž. XVIII A7, 15591592), výběrová bibliografie k rukopisu: KROPÁČEK 1952, s. 107-109, kat. č. 16, s. 44-47; VACKOVÁ 1968, s. 381, 384; PUDILOVÁ 1973, s. 38; PRAŽÁK 1980, s. 73-75; KRÁSA 1990; KRATOCHVÍLOVÁ 2005, s. 323-334; GRAHAM 2006, s. 412-414, kat. č. 84; BRODSKÝ 2012, s. 195, obr. 317; SOUČKOVÁ 2019, s. 341-343.

Viz 2 Kr 2, 9-14; více k ikonografii motivu např. HALL 1975, s.111-112; KIRSCHBAUM 1990b, s. 607-614; ROYT 2006, s. 74-75

Ikonografii monumentálních zpěvníků se věnuje zejména disertační práce Martiny Šárovcové, viz ŠÁROVCOVÁ 2011 a dále také SOUČKOVÁ 2019, s. 199-279 - v obou pracích je uvedená i další literatura k ikonografii v chorálních rukopisech.
} 
a ukončená seříznutou větévkou. ${ }^{14}$ Pod kolumnou notace je umístěna scéna Eliáše odvezeného na nebesa s přihlížejícím Elíšou - učedníkem Eliáše. ${ }^{15}$ Výjev lze $\mathrm{v}$ rámci typologie považovat za starozákonní předobraz k Nanebevstoupení. ${ }^{16}$ Výzdoba provedená na základě typologického paralelismu vychází z textu Písma, kdy se na jednom foliu vyskytuje motiv starozákonní, doplněn novozákonním. Námět ze Starého zákona je prefigurace výjevu ze zákona Nového, přičemž motiv z Nového zákona má být tomu ze Starého zákona vždy nadřazen. ${ }^{17}$ Námět Eliáše odváženého na nebesa v ohnivém voze lze tradičně považovat za předobraz k Nanebevstoupení Krista. Kristus na nebesa vystoupil, kdežto Eliáš byl na nebesa odvezen. ${ }^{18}$ Srovnání se nabízí i s miniaturami stejného námětu, provedenými M. Hutským v Lomnickém graduálu na fol. 419r ${ }^{19}$ a v Graduálu Sixta z Ottersdorfu na fol. 396r, ${ }^{20}$ kde jsou však iluminace rozvedeny o propracovaný zadní plán s časově následujícím dalším motivem. Jedná se o zardoušení chlapců, již se posmívali Elíšovi - učedníkovi Eliáše, protože byl plešatý, medvědicemi. ${ }^{21}$

$\mathrm{Na}$ fol. $103 \mathbf{r}$ (viz obr. 2) se na pozadí těla iniciály $\mathrm{S},{ }^{22}$ které tvoří fialový akant, nachází zobrazení holubice Ducha svatého na nebesích. ${ }^{23}$ Po pravé straně lze poté sledovat akantovou rozvilinu se zlatými kapkami, kterou ukončuje seříznutá větvička. Pod kolumnou notace se dále objevuje křest etiopského komorníka královny Kandacés jáhnem Filipem. ${ }^{24}$ Komorník je zobrazen jako mouřenín, zatímco exotičnost jeho sluhy, jenž hlídá koně, je demonstrována turbanem, který má na hlavě. Tento výjev z knihy Skutků je obvyklou scénou výzdoby na straně určené k Letnicím pro zpěvníky v 2. polovině 16. století. Lze se s ním setkat např. ve Žlutickém graduálu na fol. $215 \mathrm{r}^{25}$ nebo na fol. 382r Graduálu Jakuba Sklenáře. ${ }^{26}$

Ve starší literatuře je uvedeno, že se na fol. 143r (viz obr. $3)^{27}$ nachází v iniciále S patrně Zkáza Sodomy a v borduře pod kolumnou výjev Abrahama ${ }^{28}$ prosícího anděly o Záchranu Sodomy. ${ }^{29}$ Fol. 143 r uvádí rubrika ,O swaté Trogicy “ a samotná iniciála $\mathrm{S}$ incipit , Swate trogicy “ čili tři plameny ve vnitřním poli litery $\mathrm{S}$ budou dle mého názoru spíše symbolizovat

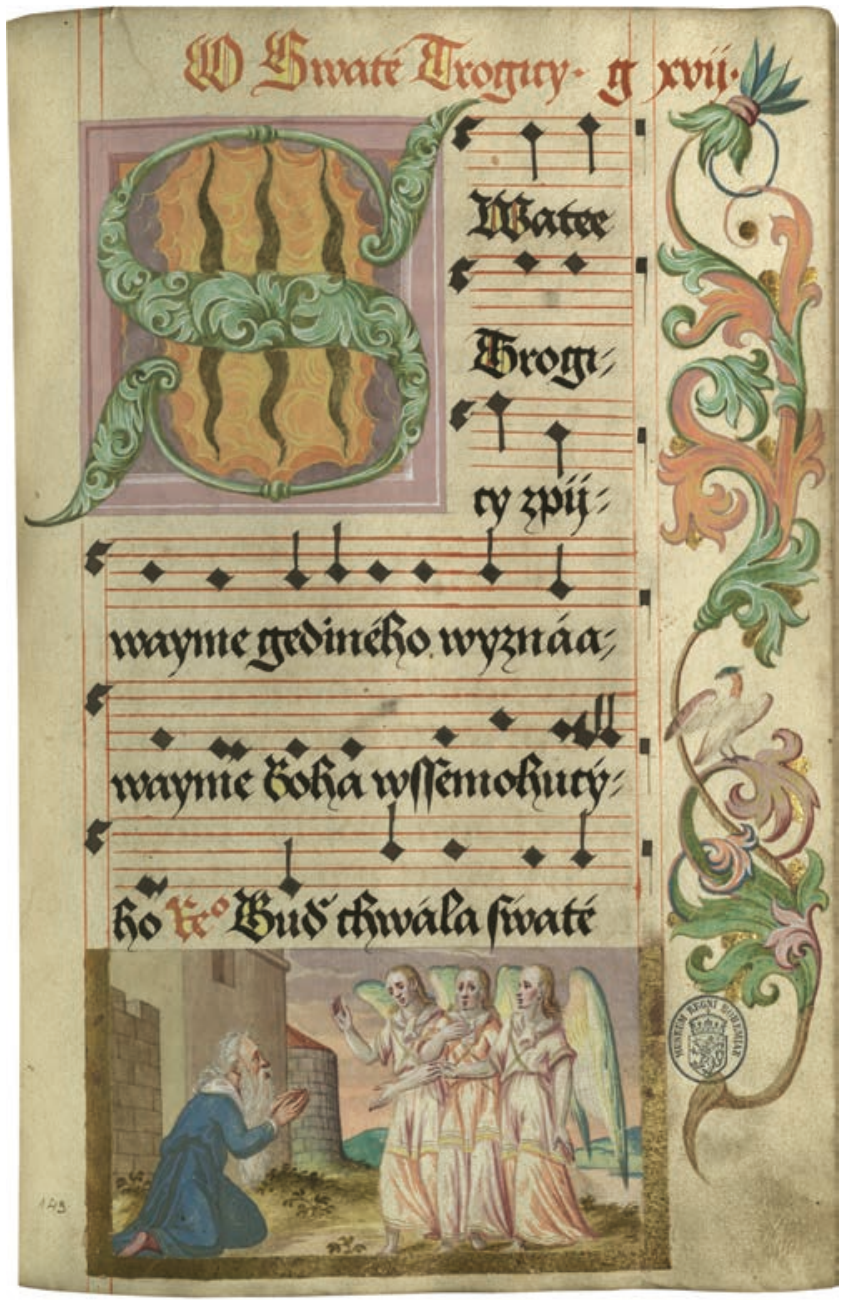

Obr. 3. Písně chval božských. Praha, Knihovna Národního muzea, oddělení rukopisů a starých tisků, sign. I A 16, 60. léta 16. století, fol. 143r. Foto: KNM.

\footnotetext{
${ }^{14} \mathrm{Na}$ ornamentiku v rukopisech se zvláště zaměřuje Viktor Kubík, který ve svých studiích rozčlenil jednotlivé typy akantů. Viz např. jeho studie KUBÍK 2007-2008, s. 65-99; KUBÍK 2010, s. 109-223. Přínosné jsou i další autorovy studie KUBÍK 2011, s. 113-241; KUBÍK 2013, s. 29-205; KUBÍK 2014, s. 155-200; KUBÍK 2015, s. 93-209.

${ }^{15}$ Viz 2 Kr 2, 9-14; více k ikonografii motivu např. HALL 1975, s.111-112; KIRSCHBAUM 1990b, s. 607-614; ROYT 2006, s. 74-75

${ }^{16}$ Ikonografii monumentálních zpěvníků se věnuje zejména disertační práce Martiny Šárovcové, viz ŠÁROVCOVÁ 2011 a dále také SOUČKOVÁ 2019, s. 199-279 - v obou pracích je uvedená i další literatura k ikonografii a chorálním rukopisům.

${ }^{17} \mathrm{~K}$ výzdobě vytvořené na základě typologického paralelismu zvl. ROYT 2006, s. 284-296. Typologie má své místo v křest’anské ikonografii již ve středověku, na př́kladu cyklu z emauzského kláštera ji rozvádí např. KUBÍNOVÁ 2012, s. 107-112.

${ }^{18}$ Viz ROYT 2006, s. 289.

${ }^{19}$ Lomnický graduál - I. díl (Praha, Národní knihovna České republiky, sign. XVII A 53a) 1578, publikováno v SOUČKOVÁ 2019 , s. 110 , obr. 89.

${ }^{20}$ Graduál Sixta z Ottersdorfu (Praha, Národní knihovna České republiky, sign. XXIII B 2) 1573-1599, publikováno v SOUČKOVÁ 2019, s. 110, obr. 90 .

${ }^{21} \mathrm{Viz} 2 \mathrm{Kr} 2,23-24$

${ }^{22}$ Fol. 103r má rubriku „, O Duchu swatém. Bohu prawém“. Iniciála S uvádí incipit „Seslání Ducha swatého slawíme“.

${ }^{23}$ K ikonografii zobrazení Ducha svatého např. HALL 1975, s. 108.

${ }^{24}$ Viz Sk 8, 26-39. K ikonografii motivu v chorálních rukopisech např. GRAHAM 2006, s. 107; ŠÁROVCOVÁ 2011, s. 51.

${ }_{25}$ Žlutický graduál (Praha, Památník národního písemnictví, sign. TR I 27, 1558-1565), výběrová bibliografie k rukopisu: VOCEL 1859, s. 10-14; CHYTIL 1906, s. 183; KROPÁČEK 1952, s. 99-106, kat. č. 14, s. 35-42; KOUDELKA 1958; VACKOVÁ 1968, s. 380; PUDILOVÁ 1973, s. 40; MALINOVSKÝ 2002; GRAHAM 2006, s. 501-506, kat. č. 111; BRODSKÝ 2008; SOUČKOVÁ 2010; ŠÁROVCOVÁ 2010b, kat. č. XIV/14, s. 466-467; BRODSKÝ 2012, s. 43, 79, 83, 84, obr. 63, 71, 72, 492; SOUČKOVÁ 2019, s. 337-340. Rukopis je digitalizován, viz Manuscriptorium Digital Library of Written Cultural Heritage [online]. Národní knihovna České republiky. [Cit. 23. 7. 2019]. Dostupné z: http://manuscriptorium.com ${ }^{26}$ Graduál Jakuba Sklenáře, publikováno v SOUČKOVÁ 2019, s. 125, obr. 111.

${ }^{27}$ Fol. 143r má rubriku „O Swaté Trogicy“. Litera S uvádí incipit „, Swaté trogici zpívajme“.

${ }^{28}$ K ikonografii motivů s Abrahamem např. KIRSCHBAUM 1990b, s. 20-35.

${ }^{29}$ BRODSKÝ 2012, s. 23.
} 
Nejsvětější trojici. ${ }^{30}$ Velice podobná iniciála se nachází na fol. 119r Kř́žovnického graduálu. ${ }^{31}$ I zde je vyobrazena na foliu s rubrikou k Nejsvětější Trojici, a navíc se na této straně neobjevuje žádný figurální výjev, který by naznačoval, že se jedná o abstraktní znázornění požáru - čili zkázy Sodomy.

Miniaturu umístěnou do bordury pod kolumnu notace Písní chval božských na fol. 143r lze tedy identifikovat jako navštívení andělů u Abrahama. Andělští hosté prorokovali Abrahamovi narození syna a zničení Sodomy, při němž byl zachráněn pouze Abrahamův synovec Lot a jeho dcery. V rámci typologického paralelismu se výjev jeví jako předobraz k Nejsvětější Trojici. ${ }^{32}$ Scéna, kdy je Abraham navštíven anděly, ${ }^{33}$ časově v knize Genesis předchází části, kde figuruje Abraham jako př́mluvce a modlitebník. Abraham návštěvníky pohostil a pak je šel vyprovodit. Za Sodomu se přimlouvá př́mo u Hospodina, ne u andělských hostů, ${ }^{34}$ i když musíme brát v úvahu, že zobrazení biblické scény neilustruje vždy text Písma přesně tak, jak je popsán v Bibli. Dekoraci na fol. 143 r doplňuje v borduře barevná rozvilina, složená z palmet akantu se zlatými kapkami. Ornamentální výzdobu obohacuje opeřenec, jenž sedí zhruba uprostřed rozviliny, která je ve spodní části ukončena seříznutou větévkou.

$\mathrm{Na}$ fol. 167r (viz obr. 4) ${ }^{35}$ se v iniciále G nachází scéna Poslední večeře, ${ }^{36}$ prričemž postavu Jidáše iluminátor umístil za tělo litery $\mathrm{G}$, mimo její vnitřní pole. Stejné kompoziční rozvržení Poslední večeře, při kterém Jidáš stojí s měšcem v ruce vně hlavní scény, se vyskytuje v Graduálu Jakuba Sklenáře na fol. $402 \mathrm{v}^{37}$ nebo v Křižovnickém graduálu na fol. $223 \mathrm{r}^{38}$ Všechny malované iniciály vykazují nejen shodnou kompozici, ale i stejné stylové znaky kresebnosti miniatur. V Katalogu iluminovaných rukopisủ Knihovny Národního muzea je výjev v borduře pod kolumnou notace na fol. 167r označen jako Anděl posilující chudého. ${ }^{39}$ Mnohem pravděpodobněji se však jedná o starozákonní motiv Spícího Eliáše, kterému anděl přináší vodu a chléb, ${ }^{40}$ což lze tradičně považovat za prefiguraci k Poslední večeři ${ }^{41} \mathrm{~V}$ graduálech, kde se na foliu k svátku Božího těla objevuje vyobrazení Poslední večeře, se velice často můžeme setkat s miniaturou Eliáše s andělem, nap̌r. ve Staroméstském graduálu na fol. $157 \mathrm{r}^{42}$ nebo v Graduálu Lomnice nad Popelkou na fol. 22r. ${ }^{43}$ Stylově je miniatura př́buzná s iluminací shodného motivu z Českého zpěvníku od dominikánů z fol. $212 \mathrm{v}^{44}$ či s iniciálou, která zachycuje ve svém vnitřním poli scénu Jákobova žebříku z Graduálu Jakuba Sklenáre z fol. 468v. ${ }^{45}$ Motiv spícího vousatého muže lze tedy $\mathrm{v}$ podobné kompozici sledovat na třech miniaturách vytvořených Matyášem Hutským z Křivoklátu a u všech se objevují stejné stylové znaky, vykazující zkratkovitě nahozenou obličejovou fyziognomii a lazurní formu malby. Figurální výzdobu v Písních chval božských na fol. 167r dále doplňuje akantová rozvilina se zlatými kapkami, ukončená ve spodní části uříznutou větévkou.

Poslední iluminovanou stranou je fol. 216r (viz obr. $5)^{46}$ s rubrikou „O swatém Janu“, na níž se dominantní jeví malovaná ornamentální litera $\mathrm{S}$, která uvádí incipit „Swatého Jana Krzitele“. V tomto př́padě lze souhlasit s P. Brodským, ${ }^{47}$ který výjev pod kolumnou notace jasně určuje jako stětí sv. Jana Křtitele. ${ }^{48}$ Iluminátor se omezuje pouze na zobrazení dvou postav ve výjevu - klečícího sv. Jana Křtitele, jenž je oděn do svého tradičního oděvu z kožešin, ${ }^{49}$ a popravčího, který má na sobě renesanční kostým. Ten se skládá ze svrchní části, jež je opatřena průstřihy - typickým prvkem renesanční módy - a nápadnými nohavicemi - tzv. plundry, které jsou sešity z různých látek do tvaru laloků, mezi nimiž jsou protaženy pevné pásky, tvořící vrchní vrstvu kalhot. ${ }^{50} \mathrm{Na}$ ostatních figurálních miniaturách $\mathrm{v}$ tomto rukopise není použit renesanční kostým - dobový oděv. Iluminátor většinou postavy „obléká“ do neurčitých barevných tóg, majících patrně napodobit iluzi biblických časů.

\footnotetext{
${ }^{30}$ K typům Nejsvětější Trojice zvláště ROYT 2006, s. 170-179.

${ }^{31}$ Křižovnický graduál - I. díl, publikováno v SOUČKOVÁ 2019, s. 245, obr. 214.

${ }^{32}$ Výčet předobrazů v rámci typologického paralelismu je publikován např. v ROYT 2006, s. 288-296.

${ }^{33}$ Viz Gn 18, 1-15.

${ }^{34}$ Viz Gn 18, 20-33.

${ }^{35}$ Fol. $167 \mathrm{r}$ má rubriku , O Slawné wečeři Páně“. Litera G uvádí incipit „, Gežíši... “

${ }^{36}$ Viz Mt 26,17-29;Mk 14,12-25; L 22,7-23; J 13,21-30, více k ikonografii námětu např.: HALL 1975, s.188-189; KIRSCHBAUM 1990a, s. 10-18; ROYT 2006, s. 244-247.

${ }^{37}$ Graduál Jakuba Sklenáře, publikováno v SOUČKOVÁ 2019, s. 129, obr. 116.

${ }^{38}$ Křižovnický graduál - I. díl, publikováno v SOUČKOVÁ 2019, s. 127, obr. 114.

${ }^{39}$ BRODSKÝ 2000, s. 6.

${ }^{40}$ Viz 1 Kr 19,1-8; k ikonografii námětu např.: HALL 1975, s. 111; ROYT 2006, s. 74.

${ }^{41}$ HALL 1975, s. 189.

${ }^{42}$ Staroměstský graduál (Praha, NK ČR, sign. XVII A 40, 1561-1567), výběrová bibliografie k rukopisu: BERINGER 1890-1892, s. 87-88; TRUHLÁR̆ 1906, s. 17-18; URBÁNKOVÁ 1957, s. 24; VACKOVÁ 1968, s. 382; VACKOVÁ 1989, s. 95; KRÁSA 1990, s. 115; GRAHAM 2006, s. 380-383; KRATOCHVÍlOVÁ 2005, s. 323-334; SOUČKOVÁ 2012; BRODSKÝ 2012, s. 43; SOUČKOVÁ 2019, s. 366-368. Rukopis je digitalizován, viz Manuscriptorium - Digital Library of Written Cultural Heritage [online]. Národní knihovna České republiky. [Cit. 23.7. 2019]. Dostupné z: http://manuscriptorium.com .

${ }^{43}$ Lomnický graduál - II. díl (Praha, NKČR, sign. XVII. A. 53b, 1580-1586), výběrová bibliografie k rukopisu: LHOTA 1861, s. 76-78; KROPÁČEK 1952, s. 134-137, kat. č. 26, s. 69-72; URBÁnKovÁ 1957, s. 24-25; VACKOVÁ 1968, s. 383-384; VACKOVÁ 1989, s. 97; SVOBODOVÁ 1996, s. 17-18, kat. č. 8; ŠRONĚK 1997, s. 56; GRAHAM 2006, s. 394-397, kat. č. 78; ŠÁROVCOVÁ 2011 , s. 77\#-79\#, kat. č. 27b; SOUČKOVÁ 2019, s. 388-392. Rukopis je digitalizován, viz Manuscriptorium - Digital Library of Written Cultural Heritage [online]. Národní knihovna České republiky. [Cit. 23. 7. 2019]. Dostupné z: http://manuscriptorium.com

${ }^{44}$ Český zpěvník od dominikánů (Praha, Národní archiv, sign. ČR 410) asi 60.-80. léta 16. století, publikováno in SOUČKOVÁ 2019, s. 119, obr. 103.

${ }^{45}$ Graduál Jakuba Sklenáře, publikováno v SOUČKOVÁ 2019, s. 121, obr. 105.

${ }^{46}$ Fol. 216r má rubriku ,, O Swatém Janu Křtiteli“. Litera S uvádí incipit „,Swatého Jana Křtitele... “

${ }^{47}$ BRODSKÝ 2000, s. 6.

${ }^{48}$ Viz Mt 14, 10; Mk 6, 27; k ikonografii motivu HALL 1975, s. 174; ROYT 2006, s. 93.

${ }^{49} \mathrm{~K}$ ikonografii sv. Jana Křtitele např. ROYT 2006, s. 92-94.

${ }^{50}$ K nohavicím a kalhotám užívaným v období renesance zvl. PILNÁ 2018, s. 76-82. K renesančnímu oděvu obecně zvl. KYBALOVÁ 1996.
} 


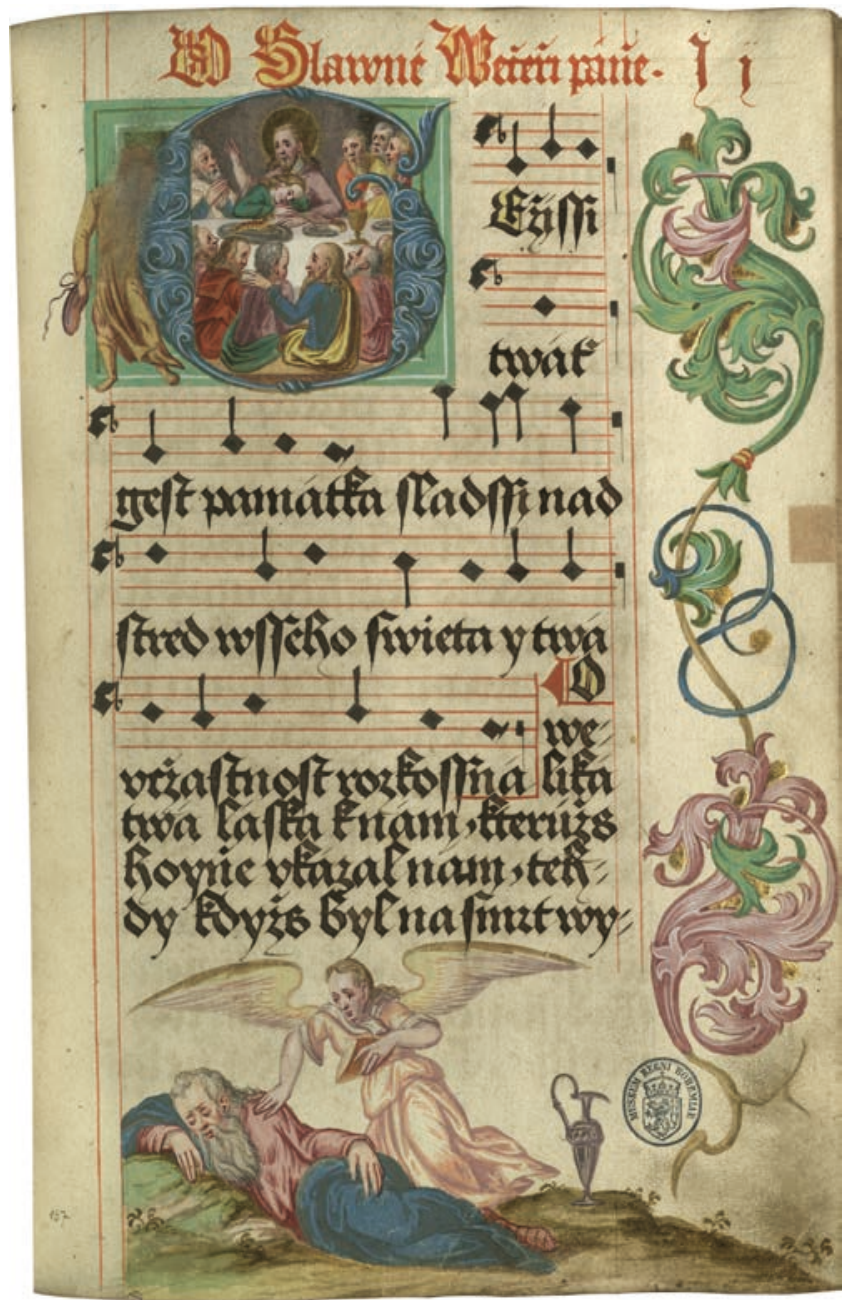

Obr. 4. Písně chval božských. Praha, Knihovna Národního muzea, oddělení rukopisů a starých tisků, sign. I A 16, 60. léta 16. století, fol.167r. Foto: KNM.

Ornamentální dekorace na fol. 216r je zastoupena zmíněnou malovanou iniciálou $\mathrm{S}$ a akantovou rozvilinou se zlatými kapkami, která je ukončená seříznutou větévkou.

\section{Shrnutí}

Výzdoba rukopisu nepředstavuje rozhodně to nejkvalitnější, co v 16. století v rámci knižní malby vzniklo. Nicméně jednotlivé miniatury se drží tradičního ikonografického rozvržení v iluminovaných knihách, při kterém lze sledovat výzdobu soustředěnou do vnitřních polí iniciál a pod kolumnu notace. Figurální motivy doplňují jednoduché akantové rozviliny v bordurách se zlatými kapkami, ukončené vždy seříznutou větvičkou. Na třech stranách se zde objevuje dekorace vytvořená na základě typologického paralelismu, tedy novozákonní výjev ve vnitřním poli iniciály doplňuje starozákonní motiv v borduře, který je o stupínek níž na žebříčku

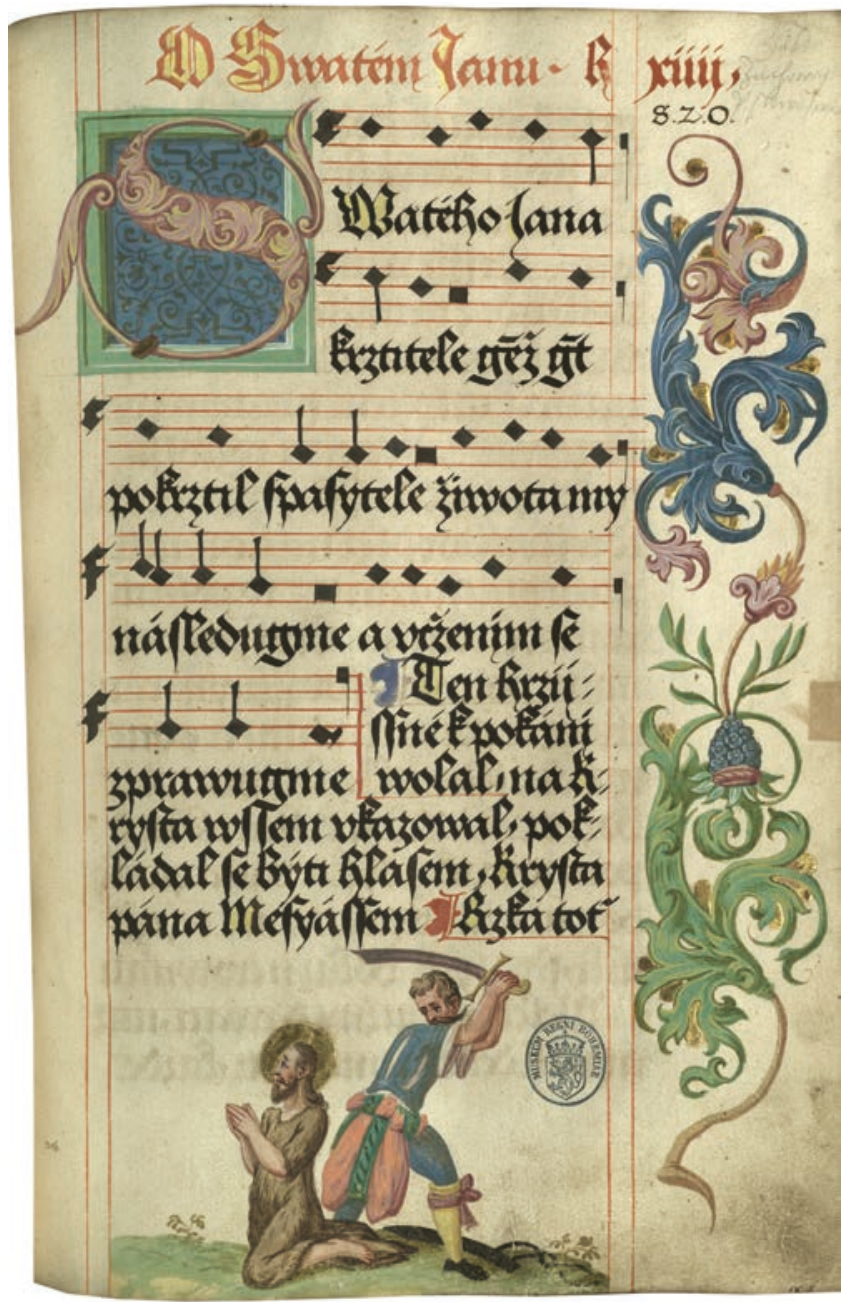

Obr. 5. Písně chval božských. Praha, Knihovna Národního muzea, oddělení rukopisů a starých tisků, sign. I A 16, 60. léta 16. století, fol. 216r. Foto: KNM.

spásy než námět novozákonní. ${ }^{51}$ Stylově navíc iluminace odpovídají podobnému rukopisu tzv. Českému zpěvníku od dominikánů ${ }^{52}$ jenž je uchováván v Národním archivu v Praze. Podobnost se jeví zvláště u miniatury se Spícím Eliášem, kterého lze v dominikánském zpěvníku sledovat ve vnitřním poli iniciály na fol. $212 \mathrm{v}$.

Schematičnost a určitá kresebnost jsou tedy charakteristické pro iluminátora Písní chval božských, kterým byl s největší pravděpodobností Matěj Hutský z Křivoklátu. ${ }^{53}$ Za poznávací znamení M. Hutského můžeme považovat i již výše zmíněnou Poslední večeři s Jidášem stojícím mimo vnitřní pole iniciály, jež se ve stejné podobě vyskytuje ve třech zpěvnících. Tato kompozice se jeví jako výsledek vlastní invence malíře, který pravděpodobně nepracoval v takové míře s grafickými předlohami, jak bylo obvyklé u jiných iluminátorů jeho doby. ${ }^{54}$

\footnotetext{
${ }^{51} \mathrm{Na}$ ff. $79 \mathrm{r}, 143 \mathrm{r}$ a $167 \mathrm{r}$.

${ }^{52}$ Český zpěvník od dominikánů (Praha, Národní archiv, fond Řádový archiv dominikánů, sign. ŘD 410, asi 70.-80. léta 16. století), výběrová bibliografie k rukopisu: GRAHAM 2006, s. 506-508; ŠÁROVCOVÁ 2011, s. 203\#-204\#; SOUČKOVÁ 2014, s. 82-87; SOUČKOVÁ 2019 , s. $377-381$.

${ }^{53}$ BRODSKÝ 2000, s. 6.

${ }^{54}$ K práci iluminátorů s grafickými předlohami např. SOUČKOVÁ 2019, s. 173-198.
} 


\section{Závěr}

Cílem tohoto článku je především shrnout dekoraci rukopisu Písni chval božských a upozornit na její náměty, které vycházejí z biblické ikonografie. J. Vacková již ve svém článku „Podoba a prííčiny anachronismu“ publikovaném v časopise Umění v roce 1968 řadí rukopis do třetí vrstvy iluminovaných chorálních knih, pro niž je podle ní charakteristické , uvolnění formy, kdy miniatura definitivně ztrácí svoji drobnomalebnou podobu a méní se v akvarelovou, či jasným průhledným kvašem lavírovanou perokresbu na papíre ".55 Volnější způsob provedení a př́lišná kresebnost v této rukopisné knize však může být dána i finančními možnostmi objednavatele, který vzhledem k nákladnosti miniatur mohl preferovat tuto formu dekorace. Je také možné, že pocházel z měšt'anské vrstvy, jež v 16. století objednávala ručně psané monumentální kodexy, určené pro sborový zpěv na kůrech městských kostelů. Objasnění provenience zpěvníku ale zůstává úkolem pro další studium rukopisu. V Čechách se iluminované kancionály a graduály obecně staly silným uměleckým a sociálním výrazem doby a zároveň dokladem o podílu měšt’anstva na vývoji umění v 16 . století.

\section{Seznam citovaných rukopisů:}

Český zpěvník od dominikánů. Praha, Národní archiv, sign. ČR 410, asi 60.-80. léta 16. století.

Český zpěvník od dominikánů. Praha, Národní archiv, fond Řádový archiv dominikánů, sign. ŘD 410, asi 70.-80. léta 16. století.

Lomnický graduál - I. díl. Praha, Národní knihovna ČR, sign. XVII A 53a, 1578.

Lomnický graduál - II. díl. Praha, Národní knihovna ČR, sign. XVII A 53b, 1580-1586.

Graduál Jakuba Sklenáře. Praha, Národní knihovna ČR, sign. XVII B 21, 1572.

Graduál Sixta z Ottersdorfu. Praha, Národní knihovna ČR, sign. XXIII B 2.

Křižovnický graduál - I. díl. Praha, Národní knihovna ČR, depositum knihovny Rytířského řádu Křižovníků s červenou hvězdou, sign. Křiž. XVIII A7, 1559-1592.

Malostranský graduál. Praha, Národní knihovna ČR, sign. XVII A 3, 1572.

Písně chval božských. Praha, Knihovna Národního muzea, oddělení rukopisů a starých tisků, sign. I A 15, 2. pol. 16. století. Písně chval božských. Praha, Knihovna Národního muzea, sign. I A 16, 60. léta 16. století.

Staroměstský graduál. Praha, Národní knihovna ČR, sign. XVII A 40, 1561-1567.

\section{Seznam použité literatury:}

BARTOŠ 1926: BARTOŠ, František Michálek. Soupis rukopisů Národního musea v Praze. Svazek I. Praha: Melantrich, 1926.

BERINGER 1890-1892: BERINGER, Jan. O českých miniaturách. (Z literární pozůstalosti architekta Antonína
Bauma uveřejňuje Antonín Beringer). Památky archaeologické a místopisné XV, 1890-1892, s. 86-88, 146-147.

BRODSKÝ 2000: BRODSKÝ, Pavel. Katalog iluminovaných rukopisů Knihovny Národního muzea v Praze = Catalogue of the illuminated manuscripts of the Library of the National Museum, Prague, Praha: KLP, 2000.

BRODSKÝ 2008: BRODSKÝ, Petr. Žlutický kancionál 1558-2008. 450 let Žlutického kancionálu. Sokolov: Fornica, 2008. (Petr Brodský neni totožný s Pavlem Brodským - nejedná se o chybu.)

BRODSKÝ 2012: BRODSKÝ, Pavel. Krása českých iluminovaných rukopisů. Praha: Academia, 2012.

ČERNUŠÁK - ŠTĚDROŇ - NOVÁČEK 1965: Gracián ČERNUŠÁK, Gracián - ŠTĚDROŇ, Bohumír-NOVÁČEK, Zdenko (edd.). Československý hudebni slovník osob a institucí. Praha: Státní hudební nakladatelství, 1965.

DROBNÁ 1966: DROBNÁ, Zoroslava. Nejkrásnější iluminované rukopisy knihovny Národního muzea v Praze. Časopis Národního muzea 135, 1966, s. 233.

GRAHAM 2006: GRAHAM, Barry Frederic Hunter. Bohemian and Moravian Graduals 1420-1620. Turnhout: Brepols, 2006.

HALL 1975: HALL, James. Dictionary of Subjects and Symbols in Art. London: Murray, 1975.

CHYTIL 1906: CHYTIL, Karel. Malírstvo pražské XV. a XVI. věku a jeho cechovní kniha staroměstská z let 1490 1582. Praha: nákladem České akademie císaře Františka Josefa pro vědy, slovesnost a umění, 1906.

KIRSCHBAUM 1990a: KIRSCHBAUM, Engelbert. Lexikon der christlichen Ikonographie. Zweiter Band, Allgemeine Ikonographie, Fabelwesen-Kynokephalen. Rom: Herder, 1990

KIRSCHBAUM 1990b: KIRSCHBAUM, Engelbert. Lexikon der christlichen Ikonographie. Erster Band, Allgemeine Ikonographie, A - Ezechiel. Rom: Herder, 1990. KOUDELKA 1958: KOUDELKA, Jiří. Žlutický kancionál 1558-1958. Žlutice: MNV, 1958.

KRATOCHVÍLOVÁ 2005: KRATOCHVÍLOVÁ, Martina. K provenienci Křižovnického a Staroměstského graduálu. Umění LIII, 2005, s. 323-334.

KRÁSA 1990: KRÁSA, Josef. Epilog středověké iluminace. In: BOHATCOVÁ, Mirjam et al. Česká kniha v proménách staletí. Praha: Panorama 1990, s. 107-116.

KROPÁČEK 1952: KROPÁČEK, Jiří. České kancionály 16. století a iluminátor Fabián Puléř. Praha 1952. Diplomová práce. Univerzita Karlova v Praze. Filozofická fakulta.

KUBÍK 2007-2008: KUBÍK, Viktor. Studie k umělecko-historické terminologii středověké knižní malby. Úvodní poznámky a základní typy akantu. Studie o rukopisech XXXVII-XXXVIII, 2007-2008, s. 65-99.

KUBÍK 2010: KUBÍK, Viktor. Poznámky k „českým typům akantů“ (Studie k umělecko-historické terminologii středověké knižní malby 2). Studie o rukopisech 40, 2010, s. 109-223.

KUBÍK 2011: KUBÍK, Viktor. Typologie iniciál a základy systému výzdoby středověkých rukopisů I. Pozdně

55 VACKOVÁ 1989, s. 384. 
antické, předrománské, byzantské a románské rukopisy (Studie k umělecko-historické terminologii středověké knižní malby 3). Studie o rukopisech 41, 2011, s. 113-241.

KUBÍK 2013: KUBÍK, Viktor. Typologie iniciál a základy systému výzdoby středověkých rukopisů II. Gotické rukopisy a počátky renesanční iluminace (Studie k umělecko-historické terminologii středověké knižní malby 4). Studie o rukopisech 43, 2013, s. 29-205.

KUBÍK 2014: KUBÍK, Viktor. Poznámky ke gotické knižní malbě z jádra jihozápadních Čech. Studie o rukopisech 44, 2014, s. 155-200.

KUBÍK 2015: KUBÍK, Viktor. Typologie kaligrafických iniciál jako východisko ke studiu kreslené ornamentiky (Studie k umělecko-historické terminologii středověké knižní malby 5). Studie o rukopisech XLV, 2015, s. 93-209.

KUBÍNOVÁ 2012: KUBÍNOVÁ, Kateřina. Emauzský cyklus. Ikonografie středověkých nástěnných maleb v ambitu kláštera Na Slovanech. Praha: Artefactum, 2012.

KYBALOVÁ 1996: KYBALOVÁ, Ludmila. Renesance. Déjiny odivání. Praha: Nakladatelství Lidové noviny, 1996.

LHOTA 1861: LHOTA, Jan N. Lomnické kancionály na Vrchlabí. Památky archaeologické a místopisné IV, 1861, s. 74-78.

MALINOVSKÝ 2002: MALINOVSKÝ, Anton František. Heraldika českých renesančních graduáli̊ Litoměřického, Rakovnického a Žlutického. Praha: Klub pro českou heraldiku a genealogii, 2002.

MERHAUTOVÁ-LIVOROVÁ 1953: MERHAUTOVÁ-LIVOROVÁ, Anežka. K ikonografii mistra J. Husa. Umění I, 1953 , s. 85.

MIKOVEC 1853: MIKOVEC, Ferdinand B. Matěj Hutský z Křivoklátu. Časopis českého museum XXVII, 1853, s. 52-68.

PEŠINA 1954a: PEŠINA, Jaroslav. Další příspěvek k ikonografii upálení M. Jana Husa. Umění II, 1954, s. 253-254.

PEŠINA 1954b: PEŠINA, Jaroslav. Skupinový portrét v českém renesančním malířství. Umění II, 1954, s. 287-288.

PILNÁ 2018: PILNÁ, Veronika. Oděv v západních Čechách 15. až 17. století. Plzeň: Národní památkový ústav, územní odborné pracoviště v Plzni, 2018.

PRAŽÁK 1980: PRAŽÁK, Jiří. Katalog rukopisů křižovnické knihovny nyni deponovaných ve Státní knihovně ČSR. Praha: Státní knihovna ČSR, 1980.

PUDILOVÁ 1973: PUDILOVÁ, Jana. Dílna Jana Táborského z Klokotské Hory. Praha 1973. Diplomová práce. Univerzita Karlova v Praze. Filozofická fakulta.

PUMPRLA 2010: PUMPRLA, Václav. Knihopisný slovník českých, slovenských a cizich autorů 16.-18. století. Praha: Kabinet pro klasická studia, Filosofický ústav Akademie věd České republiky, 2010.

ROYT 2006: ROYT, Jan. Slovník biblické ikonografie. Praha: Karolinum, 2006.

TEIGE 1901: TEIGE, Josef. Jana Táborského z Klokotské Hory Zpráva o orloji staroměstském, Praha: Společnost přátel starožitností českých v Praze, 1901.

TOMAN 1947: TOMAN, Prokop. Nový slovník československých výtvarných umělců I. Praha: Tvar, 1947.

TRUHLÁŘ 1906: TRUHLÁŘ, Josef. Katalog českých rukopisů c. $k$. veřejné a universitni knihovny pražské. Praha:
Nákladem České akademie císaře Františka Josefa pro vědy, slovesnost a umění, 1906.

SOUČKOVÁ 2010: SOUČKOVÁ, Ema. Žlutický kancionál. Praha 2010. Bakalářská práce. Univerzita Karlova v Praze. Katolická teologická fakulta.

SOUČKOVÁ 2012: SOUČKOVÁ, Ema. Staroměstský graduál (NK, ČR, XVII. A. 40), 1561-1567, z dílny Jana Táborského z Klokotské Hory. Praha 2012. Diplomová práce. Univerzita Karlova v Praze. Katolická teologická fakulta. SOUČKOVÁ 2014: SOUČKOVÁ, Ema. Výzdoba graduálu z řádového archivu dominikánů. In: KRUŠINSKÝ, Rostislav - VINTROVÁ, Tereza (edd.). Bibliotheca Antiqua 2014. Sborník z 23. konference. Olomouc: Vědecká knihovna v Olomouci; Ostrava: Sdružení knihoven České republiky, s. 82-87.

SOUČKOVÁ 2019: SOUČKOVÁ, Ema. Výzdoba hudebních rukopisů Jana Táborského z Klokotské Hory. Praha: Academia, 2019.

SVOBODOVÁ 1996: SVOBODOVÁ, Milada. Katalog českých a slovenských rukopisů sign. XVII získaných Národní (Universitní) knihovnou po vydání Truhlár̆ova katalogu z roku 1906. Praha: Národní knihovna ČR, 1996.

ŠÁROVCOVÁ 2010a: ŠÁROVCOVÁ, Martina. Neznámý pražský iluminátor Adam Cibus a Písně chwal božských z roku 1587. In: VOLRÁBOVÁ, Alena (ed.). Ars linearis. Grafika a kresba českých zemí v evropských souvislostech II. Praha: Národní galerie, 2010, s. 4-11.

ŠÁROVCOVÁ 2010b: ŠÁROVCOVÁ, Martina. Žlutický graduál [katalogové heslo]. In: HORNÍČKOVÁ, Kateřina ŠRONĚK, Michal (edd.). Umění české reformace (13801620). Praha: Academia 2010, kat. č. XIV/14, s. 466-467.

ŠÁROVCOVÁ 2011: ŠÁROVCOVÁ, Martina. Ikonografie česky psaných utrakvistických graduálů. Praha 2011. Disertační práce. Univerzita Karlova v Praze. Filozofická fakulta.

ŠRONĚK 1997: ŠRONĚK, Michal. Pražští malíri 1600-1656: mistři, tovaryši, učednici a štolíri v Knize Staroměstského malířského cechu. Biografický slovník. Praha: Artefactum, 1997.

URBÁNKOVÁ 1957: URBÁNKOVÁ, Emma. Rukopisy a vzácné tisky pražské Universitní knihovny. Praha: SPN, 1957.

VACKOVÁ 1968: VACKOVÁ, Jarmila. Podoba a př́iciny anachronismu. Uméní XVI, 1968, s. 379-393.

VACKOVÁ 1989: VACKOVÁ, Jarmila. Závěsné malířství a knižní malba v letech 1526 až 1620. In: PETRASOVÁ, Tat'ána - LORENZOVÁ, Helena (edd.). Dějiny českého výtvarného uméní II/1. Praha: Academia, 1989, s. 93-105.

VOCEL 1859: VOCEL, Jan Erazim. Miniatury české XVI. století [separát z časopisu Památky archaeologické a mistopisné III, 1859, 241-257]. [Praha]: Jaroslav Pospíšil, 1859.

\section{Ema Součková}

Národní muzeum - Historické muzeum

oddělení starších českých dějin

Vinohradská 1

11000 Praha 1 